\title{
PERENCANAAN SISTEM PENGELOLAAN SAMPAH DI KAWASAN WISATA BUKIT KELAM KABUPATEN SINTANG
}

\author{
Merlin Naltaru $\mathbf{S}^{1}$, Rizki purnaini ${ }^{1}$, Robby Irsan ${ }^{1}$ \\ ${ }^{1}$ Program Studi Teknik Lingkungan, Universitas Tanjungpura, Pontianak \\ email: naltarumerlin@gmail.com
}

\begin{abstract}
ABSTRAK
Bukit Kelam sebagai salah satu tempat wisata yang diminati masyarakat, baik dalam daerah Kabupaten Sintang maupun dari luar Kabupaten, yang diperkirakan semakin tahun semakin meningkat pengunjungnya. Peningkatan ini tentu saja dapat meningkatkan jumlah sampah yang dihasilkan dari setiap aktivitas pengunjung dan pedagang yang ada di kawasan wisata Bukit Kelam. Penanganan sampah di kawasan wisata Bukit Kelam untuk saat ini masih menggunakan cara lama yaitu sampah dikumpulkan ke tempat pengumpulan sementara (semacam TPS) kemudian dibakar. Tujuan perencanaan ini yaitu untuk mengetahui timbulan dan komposisi sampah yang dihasilkan oleh aktivitas di kawasan wisata Bukit Kelam dan untuk merencanakan sistem pengelolaan sampah terpadu di kawasan wisata Bukit Kelam. Metode penelitian untuk mengetahui timbulan dan komposisi sampah dilakukan pada saat jumlah pengunjung tertinggi tanggal 25 Desember 2013 dan 1 Januari 2014. Titik pengambilan sampel terdiri dari 8 titik yaitu warung ( 3 buah), gedung serbaguna (1 buah), taman bermain (1 buah), dan air terjun (3buah). Perencanaan sistem pengelolaan sampah di kawasan wisata Bukit Kelam meliputi aspek teknis operasional, aspek pembiayaan dan aspek peran serta masyarakat. Aspek teknis operasional yaitu perencanaan perwadahan, pengumpulan dan pengangkutan.Total jumlah timbulan sampah organik dan sampah anorganik rata-rata di kawasan wisata Bukit Kelam yaitu $0,25 \mathrm{~m} 3 /$ hari dengan komposisi sampah organik $0,12 \mathrm{~m}^{3} /$ hari $(48,13 \%)$, plastik bekas $0,24 \mathrm{~m}^{3} /$ hari $(10,16 \%)$, botol minuman $0,96 \mathrm{~m}^{3} /$ hari $(41,18 \%)$ dan botol kaca $1,14 \mathrm{~m}^{3} /$ hari $(48,66 \%)$. Perwadahan komunal yang disediakan sebanyak 19 buah yang tersebar di beberapa tempat, pengumpulan yang dilakukan yaitu menggunakan pola pengumpulan tidak langsung dimana sampah yang berasal dari wadah individual dikumpulkan di wadah komunal oleh pedagang dan pengunjung, pengangkutan yang dilakukan menggunakan keranjang gendong dengan kapasitas $0,25 \mathrm{~m}^{3}$ sebanyak 2 buah keranjang gendong. Perencanaan TPST terdiri 3 bangunan yaitu pos jaga dengan luas lahan $4 \mathrm{~m}^{2}$ dan jumlah karyawan 1 orang; rumah kompos (tempat pemilahan, pencacahan, pengayakan, area pematangan, gudang) dengan luas $103,66 \mathrm{~m}^{2}$ dengan jumlah karyawan 4 orang; dan ruang administrasi dengan luas lahan $9 \mathrm{~m}^{2}$ dan jumlah karyawan 2 orang. Biaya investasi pembangunan TPST yaitu Rp.627.833.000,- sedangkan biaya hasil penjualan pengolahan sampah dan retribusi pengunjung, pedagang dan APBD yaitu Rp.451.200.000,- perbulan dan biaya operasional dan pemeliharaan sebesar Rp.24.912.000,- perbulan.
\end{abstract}

Kata kunci : sistem pengelolaan sampah, tempat pengolahan sampah terpadu (TPST), prinsip 3R

\begin{abstract}
Kelam hill as a tourist spot that interest for society, both in Sintang area or from outside of the district, that expected more years be more increasing visitors. This increased can certainly increased the amount of rubbish that produce from every activity of visitors and sellers. The management of rubbish in tourist area of kelam hill for this time still the old way, the way is collected the rubbish to TPS and then burned it. The purpose of this plan was to determine the pile and composition of rubbish that produce by the activity in tourist area of Kelam hill and to plan the integrated production rubbish system in tourist area of Kelam hill. A research method to determine the pile and composition of rubbish was done when the highest amount of visitors on December 25, 2013 and January 1, 2014. The Sampling consisted of 8 points stalls (3 pieces), multipurpose building (1 piece), playgrounds (1 piece), and waterfalls (3buah). The Planning of rubbish production system in the tourist area of Kelam hill covered technical operational aspects, financial aspects and aspects of community participation. Operational techniques aspects were planned of contain, collect and transport. The total amount of rubbish organic and inorganic average in
\end{abstract}


tourist area of Kelam hill was $0,25 \mathrm{~m}^{3} /$ day with organic rubbish composition $0,12 \mathrm{~m}^{3} /$ day $(48,13 \%)$, plastic scrap $0,24 \mathrm{~m}^{3} /$ day $(10,16 \%)$, beverage bottles $0.96 \mathrm{~m}^{3} /$ day $(41,18 \%)$ and glass bottles 1,14 $\mathrm{m}^{3} /$ day (48,66\%). Container communal supplied as much as 19 pieces scattered in a few places, the collection was made using a pattern where rubbish collection is not directly derived from the individual container collected by the communal container seller and visitors, the transport is done using a basket with a carrying capacity of $0,25 \mathrm{~m}^{3}$ carrying baskets as much as 2 pieces. Planning TPST consisted of 3 buildings, they are guardhouse with $4 \mathrm{~m}^{2}$ land area and 1 employe; home composting (place of sorting, counting, sifting, maturation areas, warehouses) with an area of $103,66 \mathrm{~m}^{2}$ and 4 employees; and an administration with a land area of $9 \mathrm{~m}^{2}$ and 2 employees. Investment cost of TPST developments were $R p .627 .833 .000$,- while the cost of rubbish management and the sale of levy visitors, traders and budget is Rp.451.200.000,- per month and the cost of operation and maintenance of Rp.24.912.000,- per month.

Key words: rubbish management system, integrated rubbish production facility (TPST), the principle of the $3 R$

\section{PENDAHULUAN}

Bukit Kelam merupakan salah satu tempat wisata yang berada di Kabupaten Sintang. Fasilitas yang terdapat dikawasan wisata Bukit yaitu taman bermain, air terjun, kantor informasi, gedung aula, pentas hiburan, kolam anak-anak dan lapangan tenis. Namun, fasilitas dan keindahan alam yang berasal dari Bukit Kelam itu sendiri tidak didukung dengan keindahan lingkungan di sekitar tempat wisata Bukit Kelam. Jumlah pengunjung yang datang ke tempat wisata Bukit Kelam pada tahun 2013 sebanyak 12.400 orang (Dinas Pariwisata Kabupaten Sintang, 2013).

Pada kawasan wisata Bukit Kelam tidak terdapat Tempat Pembuangan Sampah (TPS), hanya terdapat tempat sampah individual yang disiapkan oleh petugas dari pemerintah daerah, serta tempat sampah yang disiapkan oleh masing-masing pedagang. Hal ini merupakan salah satu penyebab masalah sampah tidak pernah selesai, terutama di kawasan wisata Bukit Kelam yang kemungkinan besar untuk beberapa tahun ke depan akan mengalami perkembangan jika pemerintah daerah lebih memperhatikan keindahan alam dan lingkungannya. Sehingga, perlu direncanakan Tempat Pengolahan Sampah Terpadu (TPST) yang merupakan tempat dilaksanakannya kegiatan pengumpulan, pemilahan, penggunaan ulang, pendauran ulang, pengolahan, dan pemrosesan akhir. Dimana TPST yang direncanakan dengan menerapkan prinsip 3R yaitu Reduce, Reuse, dan Recycle, Sehingga diharapkan dapat mengurangi masalah sampah di kawasan wisata Bukit Kelam.

\section{METODOLOGI PENELITIAN}

\section{A. Data Primer}

Lokasi perencanaan berada di kawasan wisata Bukit Kelam Kabupaten Sintang. Peralatan yang akan digunakan yaitu: plastik sampah, timbangan, masker, sarung tangan, kotak persegi, dan kamera digital.

Sampel sampah diambil pada hari libur atau hari raya besar karena akan ada banyak pengunjung yang datang yaitu pada tanggal 25 Desember 2013 dan 1 Januari 2014. Sampel sampah yang diambil 8 titik yaitu di gedung serbaguna ( 1 buah), warung ( 3 buah), taman bermain ( 1 buah), dan air terjun ( 3 buah). Penentuan pengambilan sampel ini dilakukan dengan metode proportionate stratified random sampling berdasarkan perkiraan banyaknya sampah yang dihasilkan (Yulistiani, 2011).

Pengukuran berat sampah dilakukan dengan langkah-langkah sebagai berikut (SNI 193964-1994) yaitu menyiapkan peralatan pengukuran yaitu timbangan; memilah sampah sesuai dengan komposisi sampah; menimbang sampah yang telah dipilah; dan mencatat hasil timbangan. 
Pengukuran volume sampah dilakukan dengan langkah-langkah sebagai berikut (SNI 193964-1994) yaitu menyiapkan peralatan pengukuran yaitu kayu ukur; mengukur panjang, lebar, dan tinggi kotak dengan kayu ukur; memilah sampah sesuai karakteristik; memasukkan sampah yang telah dipilah ke dalam kotak; mengetuk-ngetukkan kotak sebanyak tiga kali; mengukur tinggi sampah; dan mencatat hasil pengukuran.

Berat sampah yang didapat dengan cara menimbang sampel, sedangkan volume sampah didapat dengan cara mengukur kotak yang berukuran $50 \mathrm{~cm} \times 50 \mathrm{~cm} \times 60 \mathrm{~cm}$. Rumus yang digunakan untuk mengukur volume sampah dalam kotak sampling adalah:

Volume sampah $\left(\mathrm{m}^{3}\right)=$ Luas Kotak $\left(\mathrm{m}^{2}\right) \times$ Tinggi Sampah $(\mathrm{m})$

Jumlah wadah untuk setiap sumber ditentukan berdasarkan perhitungan rata-rata volume sampah perhari dibagi dengan ukuran tempat sampah yang akan digunakan pada sumber tersebut. Angka yang digunakan sebagai angka perhitungan antara organik dan anorganik pada setiap sumber adalah angka terbesar dari kedua karakteristik sampah tersebut, dimana wadah sampah dengan dua karakteristik yaitu tempat sampah organik dan anorganik. Rata-rata volume terbesar yang digunakan untuk menghitung kebutuhan perwadahan sampah.

\section{B. Data Sekunder}

Data sekunder yang diambil yaitu dengan metode wawancara langsung, untuk mengetahui kondisi pedagang dan pengunjung pada saat ini. Peralatan yang digunakan yaitu pulpen dan buku. Pada pengambilan sampel wawancara langsung ke pengunjung dan pedagang dilakukan pada saat beraktivitas di kawasan wisata Bukit Kelam. Jumlah sampel untuk wawancara pengunjung dihitung berdasarkan rumus slovin yaitu (Husein,2005):

$\mathrm{n}=\mathrm{N} /(1+\mathrm{Ne})^{\wedge} 2$

Diketahui :

$\mathrm{N}=236 \mathrm{org} / \mathrm{hari}$ (bulan Desember tahun 2013 dan Januari tahun 2014)

$\mathrm{e} \quad=10 \% \approx 0,1$

Sehingga,

$\mathrm{n}=(236 \mathrm{org} /$ hari $) /(1+236 \mathrm{org} / \text { hari } \times 0,1)^{\wedge} 2$

$=(236 \mathrm{org} /$ hari $) /(1+23,6 \mathrm{org} / \text { hari })^{\wedge} 2$

$=70,22 \approx 70$ org

Maka, jumlah sampel yang diambil untuk wawancara langsung pada bulan Desember dan bulan Januari adalah sebanyak 70 org.

Jumlah pengunjung yang di peroleh dari Dinas Pariwisata Kabupaten Sintang diproyeksikan dengan metode geometri, untuk pertumbuhan jumlah pengunjung diperoleh dari perhitungan mundur lima tahun sebelumnya. Metode geometri dipilih dikarenakan metode geometri lebih mudah dan metode ini paling mendekati kebenaran. Perhitungan proyeksi metode geometri dapat dilakukan dengan menggunakan rumus:

$$
\mathrm{Pn}=\mathrm{Po}(1+r)^{\wedge} \mathrm{n}
$$

Dimana:

$\mathrm{Pn}=$ jumlah pengunjung pada tahun ke-n (orang)

Po $=$ jumlah pengunjung tahun pertama pencatatan (orang)

$R$ = angka pertumbuhan pengunjung (\%)

$\mathrm{n}=$ jumlah tahun rencana dari $\mathrm{n}$ tahun 


\section{ANALISA DATA DAN PERENCANAAN}

\section{A. Analisis dan Perhitungan Timbulan Sampah}

Pengambilan sampel yang dilakukan pada tanggal 25 Desember 2013 dan 01 Januari 2014 diperoleh berat dan volume sampah organic dan anorganik yaitu sebagai berikut:

Tabel 1 Berat dan Volume Sampah Organik dan Anorganik Tanggal 25 Desember 2013

\begin{tabular}{|c|c|c|c|c|c|c|}
\hline \multirow{2}{*}{ Titik } & \multicolumn{2}{|c|}{ Berat Sampah } & Total & \multicolumn{2}{c|}{ Volume Sampah } & Total \\
\cline { 2 - 7 } & $\begin{array}{c}\text { Organik } \\
(\text { Kg/hari })\end{array}$ & $\begin{array}{c}\text { Anorganik } \\
(\mathrm{Kg} / \mathrm{hari})\end{array}$ & $\begin{array}{c}\text { Organik } \\
(\mathrm{Kg} / \text { hari })\end{array}$ & $\begin{array}{c}\text { Anorganik } \\
\left(\mathrm{m}^{3} / \text { hari }\right)\end{array}$ & $\begin{array}{c}\left(\mathrm{m}^{3} / \text { hari }\right) \\
\left(\mathrm{m}^{3} / \text { hari }\right)\end{array}$ \\
\hline 1 & 2,20 & 2,10 & 4,30 & 0,12 & 0,15 & 0,27 \\
\hline 2 & 2,00 & 1,90 & 3,90 & 0,09 & 0,13 & 0,22 \\
\hline 3 & 2,50 & 2,50 & 5,00 & 0,13 & 0,12 & 0,25 \\
\hline 4 & 3,00 & 3,00 & 6,00 & 0,15 & 0,15 & 0,30 \\
\hline 5 & 1,85 & 2,00 & 3,85 & 0,15 & 0,09 & 0,24 \\
\hline 6 & 0,80 & 2,30 & 3,10 & 0,08 & 0,09 & 0,16 \\
\hline 7 & 2,50 & 3,00 & 5,50 & 0,12 & 0,09 & 0,21 \\
\hline 8 & 2,00 & 1,90 & 3,90 & 0,05 & 0,15 & 0,20 \\
\hline$\Sigma$ & 16,85 & 18,70 & 35,55 & 0,88 & 0,96 & 1,84 \\
\hline Rata-rata & 2,11 & 2,34 & 4,44 & 0,11 & 0,12 & 0,23 \\
\hline
\end{tabular}

Sumber: Hasil Perhitungan, 2013

Tabel 2 Berat dan Volume Sampah Organik dan Anorganik Tanggal 1 Januari 2014

\begin{tabular}{|c|c|c|c|c|c|c|}
\hline \multirow{2}{*}{ Titik } & \multicolumn{2}{|c|}{ Berat Sampah } & Total & \multicolumn{2}{c|}{ Volume Sampah } & Total \\
\cline { 2 - 7 } & $\begin{array}{c}\text { Organik } \\
(\text { Kg/hari })\end{array}$ & $\begin{array}{c}\text { Anorganik } \\
(\mathrm{Kg} / \mathrm{hari})\end{array}$ & $\begin{array}{c}\text { Organik } \\
(\mathrm{Kg} / \mathrm{hri})\end{array}$ & $\begin{array}{c}\text { Anorganik } \\
\left(\mathrm{m}^{3} / \mathrm{hari}\right)\end{array}$ & $\begin{array}{c}\left(\mathrm{m}^{3} / \text { hari }\right) \\
\left(\mathrm{m}^{3} / \text { hari }\right)\end{array}$ \\
\hline 1 & 2,80 & 2,00 & 4,80 & 0,12 & 0,15 & 0,27 \\
\hline 2 & 2,30 & 2,00 & 4,30 & 0,09 & 0,15 & 0,24 \\
\hline 3 & 3,00 & 2,50 & 5,50 & 0,13 & 0,14 & 0,27 \\
\hline 4 & 4,00 & 3,00 & 7,00 & 0,15 & 0,13 & 0,28 \\
\hline 5 & 3,90 & 2,50 & 6,40 & 0,14 & 0,15 & 0,29 \\
\hline 6 & 2,80 & 2,30 & 5,10 & 0,11 & 0,11 & 0,23 \\
\hline 7 & 2,80 & 2,50 & 5,30 & 0,14 & 0,15 & 0,29 \\
\hline 8 & 2,00 & 1,90 & 3,90 & 0,11 & 0,10 & 0,21 \\
\hline$\Sigma$ & 23,60 & 18,70 & 42,30 & 1,00 & 1,08 & 2,07 \\
\hline Rata-rata & 2,95 & 2,34 & 5,29 & 0,12 & 0,13 & 0,26 \\
\hline
\end{tabular}

Sumber: Hasil Perhitungan,2014

Volume sampah organik dan anorganik rata-rata tertinggi pada tanggal 1 Januari 2014, hal ini disebabkan oleh banyaknya jumlah pengunjung yang datang dan semakin banyaknya pengunjung yang mengkonsumsi makanan sehingga semakin banyak pula sampah yang dihasilkan. Berikut ini merupakan persentase karakteristik sampah anorganik pada tanggal 25 Desember 2013 dan 1 Januari 2014: 
Tabel 3 Persentase Karakteristik Sampah Anorganik Tanggal 25 Desember 2013 dan 1 Januari 2014

\begin{tabular}{|c|c|c|c|c|c|c|}
\hline \multirow{2}{*}{ Titik } & \multicolumn{3}{|c|}{25 Desember 2013 } & \multicolumn{3}{c|}{ 01 Januari 2014 } \\
\cline { 2 - 6 } & $\begin{array}{c}\text { Plastik } \\
\text { Bekas }\left(\mathrm{m}^{3}\right)\end{array}$ & $\begin{array}{c}\text { Botol Minuman } \\
\left(\mathrm{m}^{3}\right)\end{array}$ & $\begin{array}{c}\text { Botol } \\
\text { Kaca }\left(\mathrm{m}^{3}\right)\end{array}$ & $\begin{array}{c}\text { Plastik } \\
\text { Bekas }\left(\mathrm{m}^{3}\right)\end{array}$ & $\begin{array}{c}\text { Botol } \\
\text { Minuman }\left(\mathrm{m}^{3}\right)\end{array}$ & $\begin{array}{c}\text { Botol Kaca } \\
\left(\mathrm{m}^{3}\right)\end{array}$ \\
\hline 1 & 0,03 & 0,05 & 0,08 & 0,04 & 0,05 & 0,08 \\
\hline 2 & 0,03 & 0,04 & 0,06 & 0,03 & 0,08 & 0,05 \\
\hline 3 & 0,02 & 0,05 & 0,05 & 0,03 & 0,05 & 0,06 \\
\hline 4 & 0,02 & 0,08 & 0,05 & 0,05 & 0,03 & 0,05 \\
\hline 5 & 0,01 & 0,03 & 0,05 & 0,03 & 0,05 & 0,08 \\
\hline 6 & 0,03 & 0,03 & 0,04 & 0,03 & 0,05 & 0,04 \\
\hline 7 & 0,03 & 0,04 & 0,03 & 0,02 & 0,05 & 0,08 \\
\hline 8 & 0,03 & 0,05 & 0,08 & 0,03 & 0,05 & 0,03 \\
\hline$\Sigma$ & 0,18 & 0,35 & 0,42 & 0,24 & 0,40 & 0,45 \\
\hline Rata-rata & 0,02 & 0,04 & 0,05 & 0,03 & 0,05 & 0,06 \\
\hline
\end{tabular}

Sumber: Hasil Perhitungan, 2014

Karakteristik sampah terdiri dari plastik bekas, botol minuman dan botol kaca sebesar $0,18 \mathrm{~m}^{3}$; $0,35 \mathrm{~m}^{3}$; dan $0,42 \mathrm{~m}^{3}$ pada tanggal 25 Desember 2013, sedangkan pada tanggal 1 Januari 2014 sebesar $0,24 \mathrm{~m}^{3} ; 0,40 \mathrm{~m}^{3}$; dan $0,45 \mathrm{~m}^{3}$. Hal ini menunjukkan bahwa pada tanggal 1 Januari 2014 jumlah sampah plastik bekas, botol minuman dan botol kaca lebih banyak dibandingkan pada tanggal 25 Desember 2013 disebabkan oleh banyaknya pengunjung yang berbelanja sehingga jumlah sampah yang dihasilkan lebih banyak.

\section{B. Proyeksi Jumlah Pengunjung dan Jumlah Timbulan Sampah}

Jumlah pengunjung yang diperoleh dari di Dinas Pariwisata selama lima tahun terakhir menjadi acuan dalam memproyeksikan jumlah pengunjung untuk lima tahun ke depan. Berikut ini perhitungan mundur dengan metode geometri:

Tabel 4 Pertumbuhan Pengunjung

\begin{tabular}{|r|r|c|c|}
\hline \multirow{2}{*}{ Tahun } & \multirow{2}{*}{ Pengunjung Eksisting } & \multicolumn{2}{|c|}{ Pertumbuhan Pengunjung } \\
\cline { 3 - 4 } & & Jiwa & Persen \\
\hline 2008 & 9700 & - & - \\
\hline 2009 & 9780 & 80 & $0,825 \%$ \\
\hline 2010 & 9500 & $(280)$ & $-2,863 \%$ \\
\hline 2011 & 9020 & $(480)$ & $-5,053 \%$ \\
\hline 2012 & 10677 & 1.657 & $18,370 \%$ \\
\hline 2013 & 12400 & 1.723 & $16,137 \%$ \\
\hline & & & $\mathbf{5 , 4 8 3 \%}$ \\
\hline
\end{tabular}

Sumber: Hasil Analisis, 2014

Berdasarkan hasil pertumbuhan jumlah pengunjung maka dapat diproyeksikan jumlah pengunjung untuk lima tahun ke depan dengan menggunakan metode geometri. Berikut ini hasil perhitungan proyeksi jumlah pengunjung lima tahun ke depan: 
Tabel 5 Proyeksi Jumlah Pengunjung

\begin{tabular}{|c|c|c|c|}
\hline Tahun & N & Rasio & Jumlah Pengunjung (Jiwa) \\
\hline 2013 & 0 & 0,05483 & 12.400 \\
\hline 2014 & 1 & 0,05483 & 13.080 \\
\hline 2015 & 2 & 0,05483 & 13.797 \\
\hline 2016 & 3 & 0,05483 & 14.554 \\
\hline 2017 & 4 & 0,05483 & 15.352 \\
\hline 2018 & 5 & 0,05483 & 16.194 \\
\hline
\end{tabular}

Sumber: Hasil Analisis, 2014

Jumlah pengunjung meningkat setiap tahunnya maka setiap hari puncak juga akan meningkat dan dapat dipastikan akan meningkat pula jumlah timbulan sampah di kawasan wisata Bukit Kelam, maka diproyeksikan jumlah timbulan sampah puncak untuk lima tahun ke depan. Berikut ini perhitungan volume timbulan sampah pada saat jumlah pengunjung tertinggi pada tahun 2018:

Diketahui :

Jumlah pengunjung tahun 2013

$=12.400$ jiwa

$=16.194$ jiwa

Jumlah pengunjung tahun 2018

$=236 \mathrm{jiwa} / \mathrm{hari}$

Jumlah pengunjung pada saat hari puncak tahun 2013

$=38,93 \mathrm{~kg} / \mathrm{hari}$

Jumlah timbulan sampah organik dan anorganik

Maka,

Jumlah pengunjung tahun 2013

Jumlah pengunjung tahun 2018

Jumlah pengunjung pada hari puncak 2013

12.400 jiwa

$=\overline{\text { Jumlah pengunjung pada hari puncak } 2018}$

236 jiwa

$=\frac{16.194 \text { jiwa }}{\text { Jumlah pengunjung pada hari puncak } 2018}$

Jumlah pengunjung pada saat hari puncak tahun $2018=\frac{3.821784}{12.400}=308$ jiwa

Maka, dapat diketahui jumlah timbulan sampah rata-rata org/hari adalah

Jumlah timbulan sampah rata-rata org/hari $=\frac{\text { volume timbulan sampah }}{\text { Jumlah pengunjung pada hari puncak } 2013}$

$$
\begin{aligned}
& =\frac{38,93 \mathrm{~kg} / \text { hari }}{236 \mathrm{org} / \mathrm{hari}} \\
& =0,165 \mathrm{~kg} / \mathrm{org} / \text { hari }
\end{aligned}
$$

Hasil perhitungan total volume timbulan sampah rata-rata di kawasan wisata Bukit Kelam sesuai dengan standar timbulan sampah untuk daerah komersil.

Jumlah timbulan sampah tahun $2018=$

jumlah pengunjung pada hari pucak 2018 x jumlah timbulan rata-rata org/hari

$$
\begin{aligned}
& =308 \text { org } \times 0,165 \mathrm{~kg} / \mathrm{org} / \text { hari } \\
& =50,82 \mathrm{~kg} / \text { hari }
\end{aligned}
$$

Perhitungan jumlah timbulan sampah di tahun 2018 menunjukkan bahwa volume timbulan sampah pada saat puncak di lima tahun yang akan datang akan meningkat sesuai dengan meningkatnya jumlah pengunjung di kawasan wisata Bukit Kelam. Berikut ini merupakan tabel proyeksi timbulan sampah: 
Tabel 6 Proyeksi Volume Timbulan Sampah

\begin{tabular}{|l|l|l|c|c|}
\hline \multirow{2}{*}{ Tahun } & $\begin{array}{c}\text { Jumlah Pengunjung Hari } \\
\text { Puncak }\end{array}$ & \multicolumn{1}{|c|}{ Sumber } & \multicolumn{2}{|c|}{ Volume Sampah } \\
\cline { 3 - 5 } & & Warung & 0,34 & 0,42 \\
\hline \multirow{4}{*}{2013} & \multirow{2}{*}{236} & Gedung Serbaguna & 0,15 & 0,14 \\
\cline { 3 - 5 } & & Taman Bermain & 0,15 & 0,12 \\
\cline { 3 - 5 } & & Air Terjun & 0,31 & 0,34 \\
\hline \multirow{3}{*}{2018} & \multirow{3}{*}{308} & Warung & 0,44 & 0,54 \\
\cline { 3 - 5 } & & Gedung Serbaguna & 0,20 & 0,18 \\
\cline { 3 - 5 } & & Taman Bermain & 0,19 & 0,16 \\
\cline { 3 - 5 } & & Air Terjun & 0,40 & 0,45 \\
\hline
\end{tabular}

Sumber: Hasil Analisis, 2014

\section{Perencanaan Teknis Operasional}

Wadah sampah yang direncanakan yaitu wadah sampah terpilah dengan bahan Highdensity Polyethylene (HDPE) kapasitasnya 60 liter untuk setiap bangunan.

Tabel 6 Jumlah Wadah Sampah di Kawasan Wisata Bukit Kelam

\begin{tabular}{|c|c|c|c|}
\hline \multirow{2}{*}{ Tahun } & \multirow{2}{*}{ Sumber } & \multicolumn{2}{|c|}{ Wadah Sampah } \\
\hline & & Organik (buah) & Anorganik (buah) \\
\hline \multirow{4}{*}{2013} & Warung & 7 & 7 \\
\hline & Gedung Serbaguna & 3 & 3 \\
\hline & Taman Bermain & 2 & 2 \\
\hline & Air Terjun & 6 & 6 \\
\hline & Jumlah & 18 & 18 \\
\hline \multirow{4}{*}{2018} & Warung & 9 & 9 \\
\hline & Gedung Serbaguna & 3 & 3 \\
\hline & Taman Bermain & 3 & 3 \\
\hline & Air Terjun & 8 & 8 \\
\hline & Jumlah & 23 & 23 \\
\hline
\end{tabular}

Sumber: Hasil Analisis, 2014

Pola pengumpulan yang akan digunakan untuk kawasan wisata Bukit Kelam yaitu pola komunal tidak langsung, karena sampah yang berasal dari wadah individual dikumpulkan menjadi satu dalam wadah komunal. Pada setiap bangunan terdiri dari beberapa wadah sampah yang diletakkan terpisah agar tersebar rata dan dekat dengan sumber, untuk setiap titik telah disiapkan 2 wadah sampah yaitu sampah organik dan sampah anorganik. Waktu pembuangan sampah dari wadah individual ke wadah komunal. Proses pengangkutan dari wadah komunal ke TPST akan dilakukan 1 hari sekali sehingga sampah yang berasal dari wadah individual harus dikumpulkan ke wadah komunal oleh setiap pemilik wadah sampah.

Alat angkut yang akan dipakai adalah keranjang gendong kapasitasnya yaitu 0,25 m3 dengan diameter 0,6 $\mathrm{m}$ dan tinggi 0,9 m. Pengadaan keranjang gendong ini direncanakan sebanyak 2 buah agar mempercepat proses pengangkutan, maka di bagi menjadi 2 bagian yaitu warung 1-3, warung $6 \& 7$, air terjun $3 \& 4$, dan taman bermain $1 \& 2$ untuk keranjang gendong 1 ; warung $4 \& 5$, air terjun $1 \& 2$, air terjun $5 \& 6$, dan gedung serbaguna $1-3$ untuk keranjang gendong 2 .

\section{Perencanaan TPST Kawasan Wisata Bukit Kelam}

TPST di kawasan wisata Bukit Kelam terdiri dari 6 bangunan yaitu pos jaga, ruang pemilahan, rumah kompos, gudang, ruang administrasi, dan toilet/WC. 
Tabel 7 Kebutuhan Luas Lahan TPST Kawasan Wisata Bukit Kelam

\begin{tabular}{|c|l|c|c|}
\hline No. & \multicolumn{1}{|c|}{ Fasilitas } & $\begin{array}{c}\text { Jumlah karyawan } \\
\text { (orang) }\end{array}$ & Luas lahan $\left(\mathrm{m}^{2}\right)$ \\
\hline 1 & Pos Jaga & 1 & 4 \\
\hline 2 & Ruang Pemilahan & 2 & 10,52 \\
\hline 3 & Rumah Kompos & 2 & 73,5 \\
\hline 4 & Gudang & - & 24 \\
\hline 5 & Ruang Administrasi & 2 & 9 \\
\hline 6 & WC Total & - & 4,5 \\
\hline \multicolumn{2}{r|}{$\quad 7$} & 125,52 \\
\hline
\end{tabular}

Sumber: Hasil Analisis, 2014

Luas lahan untuk bangunan TPST di kawasan wisata Bukit Kelam yaitu 125,52 $\mathrm{m}^{2}$ dan kebutuhan lahan untuk TPST yaitu $300 \mathrm{~m}^{2}$. Kebutuhan lahan disesuaikan dengan jumlah timbulan sampah yang ditampung oleh TPST, selain itu luas lahan disesuaikan dengan klasifikasi TPS tipe III berdasarkan SNI 3242-2008 tentang pengelolaan sampah. Rencana TPST berada pada daerah sebelah kiri warung, yang berjarak 100 meter dari warung tersebut.

\section{E. Rencana Anggaran Biaya}

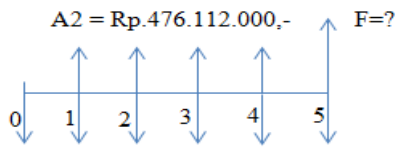

$$
\begin{aligned}
& \mathrm{i}=10 \% \\
& \mathrm{n}=5 \text { tahun } \\
& \mathrm{I}=\text { Rp.627.833.000,- } \\
& \mathrm{A} 1=\mathrm{Rp} .105 .951 .600 \\
& B C R=(A 2(P / A, i, n)) /(1+A 1(P / A, i, n)) \\
& =(R p .476 .112 .000(P / A, 10 \%, 5)) /(R p .627 .833 .000+R p .105 .951 .600(P / A, 10 \%, 5)) \\
& =(R p .476 .112 .000(3,79079)) /(R p .627 .833 .000+R p .105 .951 .600(3,79079)) \\
& =1,75 \\
& N P V=-I+A 2(P / A, i, n)-A 1(P / A, I, n) \\
& =-R p 627.833 .000+R p 476.112 .000(P / A, 10 \%, 5)-R p 105.951 .600(P / A, 10 \%, 5) \\
& =-R p 627.833 .000+R p 476.112 .000(3,79079)-R p 105.951 .600(3,79079) \\
& =R p .775 .569 .617,- \\
& i=9 \% \\
& N P V=-1+A 2(P / A, i, n)-A 1(P / A, I, n) \\
& =-R p 627.833 .000+R p 476.112 .000(P / A, 9 \%, 5)-R p 105.951 .600(P / A, 9 \%, 5) \\
& =-R p 627.833 .000+R p 476.112 .000(3,8897)-R p 105.951 .600(3,8897) \\
& i=12 \% \\
& =R p .811 .979 .907,- \\
& N P V=-I+A 2(P / A, i, n)-A 1(P / A, I, n) \\
& =-R p 627.833 .000+R p 476.112 .000(P / A, 12 \%, 5)-R p 105.951 .600(P / A, 12 \%, 5) \\
& =-R p 627.833 .000+R p 476.112 .000(3,6048)-R p 105.951 .600(3,6048) \\
& =\text { Rp.706.521.209, }-
\end{aligned}
$$

Hasil perhitungan NVP antara $i=9 \%$ dan $12 \%$ bernilai positif maka dapat dikatakan bahwa IRR $>$ MARR yaitu INVESTASI LAYAK.

\section{F. Peran Serta Masyarakat}

Pada lokasi penelitian di kawasan wisata Bukit Kelam merupakan daerah wisata yang pedagang dan pengunjungnya masih kurang peduli dengan lingkungan di sekitarnya dan kurang mengerti bagaimana cara mengolah sampah dengan prinsip 3R. Telihat dari hasil wawancara kepada pedagang di kawasan wisata Bukit Kelam: 


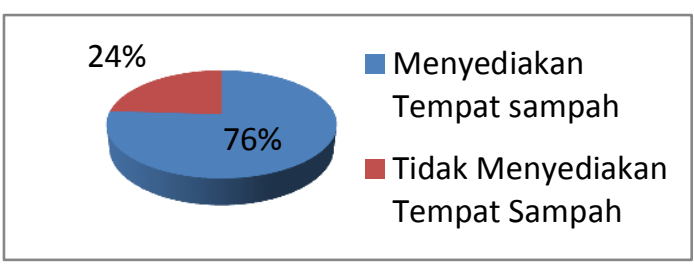

Gambar 1 Penyediaan Tempat Sampah Oleh Pedagang

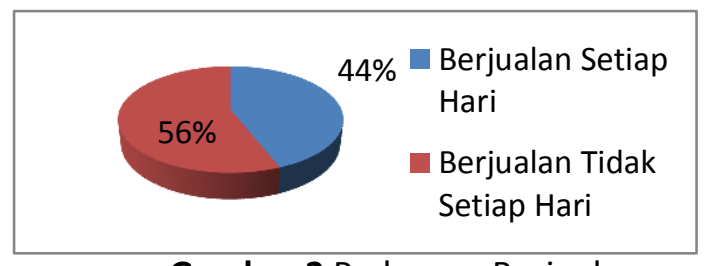

Gambar 2 Pedagang Berjualan

Gambar 1 menunjukkan bahwa pedagang mayoritas sudah memahami untuk membuang sampah pada tempatnya terlihat dari $76 \%$ pedagang yang sudah menyediakan tempat sampah. Gambar 2 menunjukkan pedagang yang berjualan setiap hari atau tidak dikarenakan tidak semua pedagang yang tinggal disekitar kawasan wisata Bukit Kelam dan berdagang bukan penghasilan pokoknya.

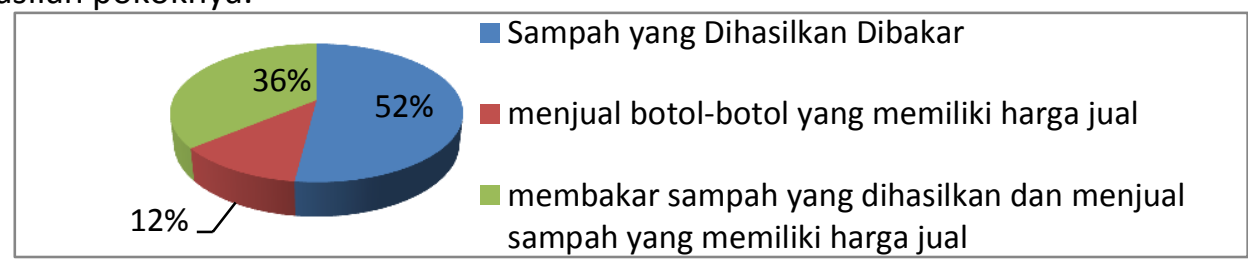

Gambar 3 Cara Pedagang Mengelola Sampah yang Dihasilkan

Gambar diatas menunjukkan bahwa pedagang bisa memanfaatkan sampah-sampah yang tidak dapat digunakan lagi dengan menjual atau membakar sampah itu sendiri, meskipun membakar bukan solusi yang baik dalam menyelesaikan masalah sampah.

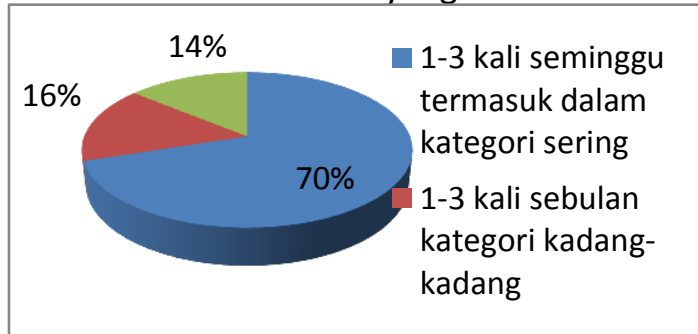

Gambar 4 Tingkat Keseringan Pengunjung Berkunjung ke Kawasan Wisata Bukit Kelam

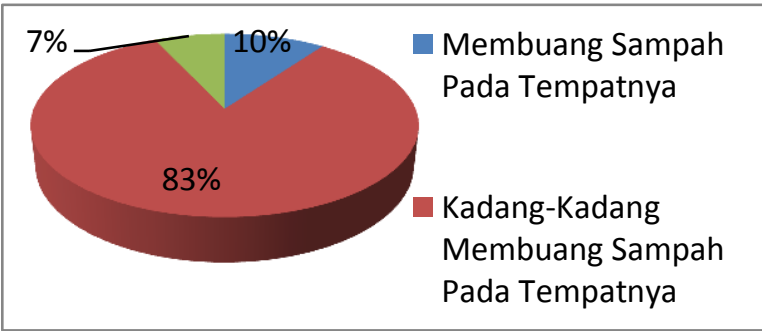

Gambar 5 Tingat Kesadaran Pengunjung Membuang Sampah

Gambar 4 menunjukkan bahwa terdapat tiga kategori tingkat keseringan pengunjung berkunjung di kawasan wisata Bukit Kelam, dimana 1-3 kali seminggu termasuk dalam kategori sering berkunjung di kawasan wisata Bukit Kelam yaitu 70\% sedangkan 1-3 kali sebulan kategori kadang-kadang yaitu $16 \%$ dan 1-3 kali setahun yaitu kategori jarang $14 \%$. Setiap pengunjung tidak semuanya membuang sampah pada tempatnya hanya $10 \%$ yang membuang sampah pada tempatnya, sedangkan yang kadang-kadang membuang sampah pada tempatnya jika ada tempat sampah terdekat saja terdapat $83 \%$ dan yang tidak membuang sampah pada tempatnya terdapat $7 \%$. Hal ini berarti masih sedikit pengunjung yang menjaga kebersihan lingkungannya.

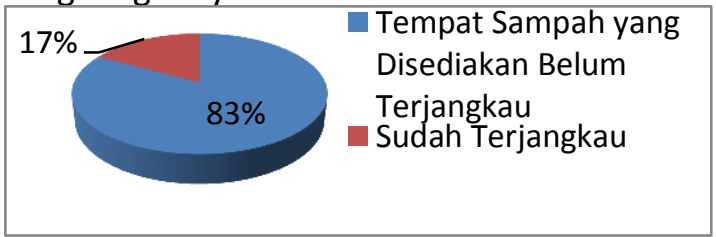

Gambar 6 Keterjangkauan Tempat Sampah yang Ada di kawasan Wisata Bukit Kelam

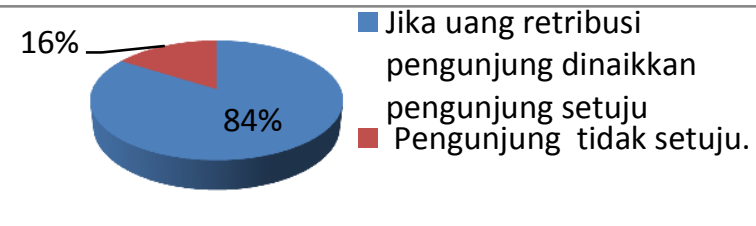

Gambar 7 Pendapat Pengunjung Tentang Kenaikan Retribusi Pengunjung 
Gambar 6 menunjukkan bahwa sebagian besar pengunjung mengatakan bahwa belum terjangkau yaitu $83 \%$ dan $17 \%$ mengatakan sudah terjangkau jumlah tempat sampahnya. Sedangkan, Retribusi pengunjung pada hari biasa yaitu Rp.5.000,- dan pada saat hari libur sebesar Rp.10.000,- uang ini merupakan salah satu pemasukan untuk pemeliharaan kawasan wisata Bukit Kelam. Pengunjung yang setuju terdapat $84 \%$ mengatakan jika uang retribusi pengunjung naik dengan syarat keindahan di kawasan wisata Bukit Kelam bisa lebih indah.

Hasil wawancara dari pedagang dan beberapa pengunjung menunjukkan bahwa keinginan mereka untuk mewujudkan terciptanya kawasan wisata Bukit Kelam yang indah dan bersih, maka dari itu penulis mengharapkan adanya kesadaran masyarakat terhadap penanganan sampah seperti membuang sampah pada tempatnya, memilah sampah organik dan anorganik, dan menyediakan tempat sampah bagi pedagang yang berjualan di kawasan wisata Bukit Kelam. Serta harapannya masyarakat tetap bersedia memberikan retribusi, bersedia mengikuti prosedur pemeliharaan kebersihan, dan mengerti dan memahami masalah kebersihan lingkungan, dengan jaminan kawasan wisata Bukit Kelam menjadi lebih indah.

\section{KESIMPULAN}

Kesimpulan yang dapat diambil berdasarkan perencanaan ini yaitu:

a. Total jumlah timbulan sampah organik dan sampah anorganik pada saat puncak tahun 2013 di kawasan wisata Bukit Kelam yaitu 1,96 $\mathrm{m}^{3} /$ hari dengan komposisi sampah organik 0,94 $\mathrm{m}^{3} /$ hari, plastik bekas $0,21 \mathrm{~m}^{3} /$ hari, botol minuman $0,38 \mathrm{~m}^{3} /$ hari dan botol kaca $0,44 \mathrm{~m}^{3} /$ hari.

b. Sistem pengelolaan sampah terpadu yang direncanakan dimulai dari teknis operasional yaitu perwadahan, pengumpulan dan pengangkutan serta pembangunan TPST (Tempat Pengolahan Sampah Terpadu). Perwadahan komunal yang disediakan sebanyak 23 buah yang tersebar di beberapa tempat, pengumpulan yang dilakukan yaitu menggunakan pola komunal tidak langsung, pengangkutan yang dilakukan menggunakan keranjang gendong dengan kapasitas $0,25 \mathrm{~m}^{3}$ sebanyak 2 buah keranjang gendong. Perencanaan TPST dengan kebutuhan lahan yaitu $300 \mathrm{~m}^{2}$ yang terdiri 3 bangunan yaitu pos jaga dengan luas lahan $4 \mathrm{~m}^{2}$; rumah kompos (tempat pemilahan, pencacahan, pengayakan, area pematangan, gudang) dengan luas $108,02 \mathrm{~m}^{2}$; dan ruang administrasi dengan luas lahan $9 \mathrm{~m}^{2}$ dan jumlah karyawan di TPST yaitu 7 orang dimana 1 orang di pos jaga, 4 orang di rumah kompos dan 2 orang di ruang administrasi. Biaya investasi pembangunan TPST yaitu Rp.627.833.000,- sedangkan biaya hasil penjualan pengolahan sampah dan retribusi pengunjung, pedagang dan APBD yaitu Rp.451.200.000,perbulan dan biaya operasional dan pemeliharaan sebesar Rp.24.912.000,- perbulan.

\section{Ucapan Terima Kasih}

Penulis mengucapkan terima kasih kepada kedua orang tua yang telah memberikan dukungan secara moril dan materil. Ucapan terima kasih pula kepada Ibu Rizki Purnaini, ST, MT dan Bapak Robby Irsan ST,M.Si selaku dosen pembimbing serta tidak lupa pula kepada temanteman Angaradasa angkatan 2010 Fakultas Teknik UNTAN yang banyak membantu dalam penyelesaian skripsi ini.

\section{Referensi}

Dinas Pariwisata Kabupaten Sintang Tahun 2013

Husein, Umar. 2005. Metode Penelitian. Jakarta: Salemba Empat

Standar Nasional Indonesia (SNI) nomor 19-3964-1994 tahun 1994 Tentang Metode Pengambilan dan Pengukuran Contoh Timbulan dan Komposisi Sampah Perkotaan.

Yulistiani, Fahrin. 2011. Perencanaan Pengelolaan Sampah Di Kawasan Selatan Universitas Tanjungpura. Pontianak: Skripsi Fakultas Teknik Jurusan Teknik Sipil Universitas Tanjungpura. 